\title{
Progesterone combined with beta human chorionic gonadotropin measurements and threatened miscarriage
}

\author{
Viroj Wiwanitkit
}

Received: 26 February 2011/ Accepted: 3 May 2012/Published online: 15 May 2012

(C) Springer-Verlag 2012

\section{Dear Editor,}

I have read the recent publication on progesterone combined with beta human chorionic gonadotropin measurements and threatened miscarriage with a great interest. Duan et al. concluded that 'Progesterone combined with $\beta$-HCG measurements may be useful for predicting the outcome of threatened miscarriage [1].' I have some concerns on this work. First, although there is a control group in this work, it is not well matched. This might imply the possible selection bias. Hence, the implication on predictive power in this work might be a misleading conclusion. In this study, a problem in selection on controls by hospital can be expected and the authors should try best to solve this problem. To solve the problem in control selection in studying, when matching cases and controls by hospital is not possible, using of secondary matching technique can be a good alternative [2]. Second, the laboratory investigation in this work has to be mentioned for quality control. There is no information on the quality control of the laboratory investigation procedure. Basically, users of microparticle enzyme immunoassay (MEIA) technique have to beware of possible errors. High variability of the measurement technique is reported [3]. The imprecision can result in erroneous laboratory result interpretation [3]. In addition, there are several causes of possible interferences on MEIA analysis including hematocrit [4] and free hormone [5]. Multiple pregnancy is another obstetric condition that limits the use of the assay in prediction of pregnancy loss [6]. Finally, although either progesterone or $\beta$-HCG measurements can be used

V. Wiwanitkit $(\bowtie)$

Wiwanitkit House, Bangkhae, Bangkok 10160, Thailand

e-mail:wviroj@yahoo.com for prediction of abortion the concern on cost of the laboratory test is required. Based on the mentioned facts, it is suggested that single progesterone test is more proper due to lower cost and easier availability [7]. As a summary, this letter raises an important laboratory concern on using progesterone and beta human chorionic gonadotropin measurements in predicting the natural course of threatened miscarriage. The exact value of this article is to address the forgotten points that can be the causes of errors in interpretation of the measurements.

Conflict of interest None.

\section{References}

1. Duan L, Yan D, Zeng W, Yang X, Wei Q (2011) Predictive power progesterone combined with beta human chorionic gonadotropin measurements in the outcome of threatened miscarriage. Arch Gynecol Obstet 283(3):431-435

2. Agudo A, González CA (1990) Secondary matching: a method for selecting controls in case-control studies on environmental risk factors. Int J Epidemiol 28(6):1130-1133

3. Tso E, Elson P, Vanlente F, Markman M (2006) The "real-life" variability of CA-125 in ovarian cancer patients. Gynecol Oncol 103(1):141-144

4. Hermida J, Fernández MC, Tutor JC (2005) Clinical significance of hematocrit interference in the tacrolimus II microparticle enzyme immunoassay: a tentative approach. Clin Lab. 51(1-2): 43-45

5. Cao Z, Swift TA, West CA, Rosano TG, Rej R (2004) Immunoassay of estradiol: unanticipated suppression by unconjugated estriol. Clin Chem 50(1):160-165

6. Lower AM, Yovich JL (1992) The value of serum levels of oestradiol, progesterone and beta-human chorionic gonadotrophin in the prediction of early pregnancy loss. Hum Reprod 7(5):711-717

7. Osmanağaoğlu MA, Erdoğan I, Eminağaoğlu S, Karahan SC, Ozgün S, Can G, Bozkaya H (2010) The diagnostic value of betahuman chorionic gonadotropin, progesterone, CA125 in the prediction of abortions. J Obstet Gynaecol 30(3):288-293 